DOI: 10.2478/romneu-2014-0029

\title{
Asymptomatic spina bifida occulta involving sacrum in an elderly female
}

\author{
Amit Agrawal, G. Malleswara Rao \\ Professors of Neurosurgery, Department of Neurosurgery, Narayna Medical College Hospital, \\ Chinthareddypalem, Nellore, Andhra Pradesh (India)
}

It has been estimated that $20 \%$ of all myelomeningoceles involve the sacral level and majority of these patients with sacral level lesions have fewer complications than with high level lesions. (1-5)

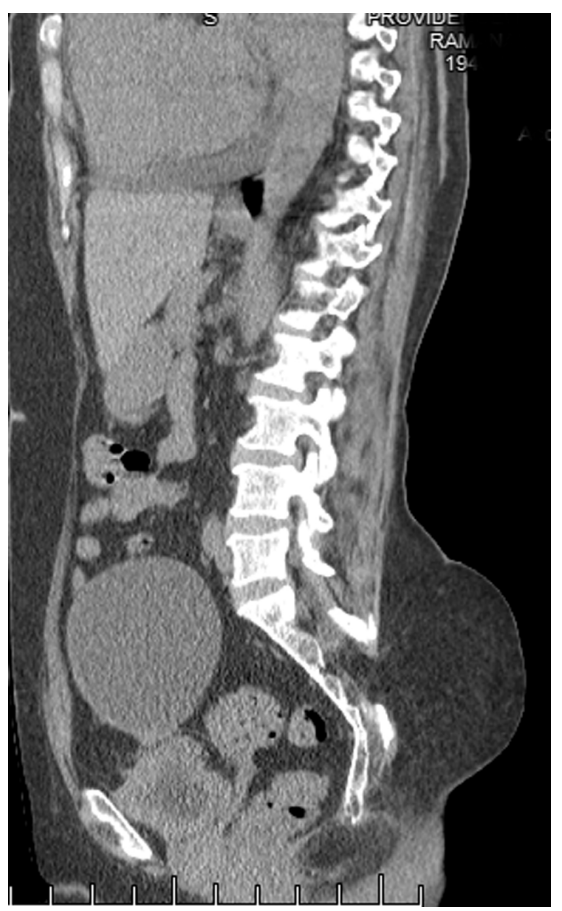

Figure 1 - Posterior view of the sacrum shows a dry bone specimen of sacral spina bifida occulta, where there is failure of closure of the sacral canal at all sacral levels
A 60 year female presented with low back pain of two year duration, non-radiating in nature but increased by bending forward. There was no history of bowel or bladder disturbances. She had swelling over low back region since childhood not associated with pain. Her general and systemic examination was normal. There was diffuse, non-tender, non-pulsatile swelling over sacral region. Skin over the swelling was healthy. Plain lumbosacral x-ray demonstrated a sacral bone defect. Pelvic computed tomography (CT) showed a defect at the dorsal aspect of the sacrum with diffuse soft tissue swelling (Figure 1). Patient responded to conservative management and physiotherapy. There are many reports on the incidence of sacral spina bifida occulta and it has been suggested that $90-100 \%$ of patients with a sacral level lesion are ambulant. (1, 6-10) The reported clinical significance of sacral spina bifida occulta ranges from an anatomical variant of little or no importance on its own to a very important cause of meningomyelocele or neurological deficits. (1, 6, 10-17) In absence of external manifestations occult spina bifida of the sacrum can be associated with a number of 
conditions including backache, posterior disc herniation, enuresis and functional disorders of the lower urinary tract, and neurological abnormalities of the feet. $(10,18-20)$ It has been hypothesized that the absence of the first sacral spinous process and the ligaments that normally run between it and the spinous process of the fifth lumbar vertebra spina bifida occulta may be associated with low back pain. (21) Awareness and knowledge of the congenital defect of sacrum must be considered before undertaking any procedure on the sacrum (i.e. caudal epidural block, internal fixation via transpedicular and lateral mass screws) as if the anomaly is overlooked it can lead to serious complications. $(2,5,22)$

\section{Correspondence:}

Dr Amit Agrawal

Professor of Neurosurgery

Department of Neurosurgery

Narayna Medical College Hospital

Chinthareddypalem

Nellore-524003

Andhra Pradesh (India)

Email-dramitagrawal@gmail.com dramit_in@yahoo.com

Mobile- +91-8096410032

\section{References}

1.Brinker MR, Rosenfeld SR, Feiwell E, Granger SP, Mitchell DC, Rice JC. Myelomeningocele at the sacral level. Long-term outcomes in adults. The Journal of bone and joint surgery American volume 1994;76:12931300 .

2.SENOGLU N, SENOGLU M, GUMUSALAN Y. Total spina bifida occulta of the sacrum. International Journal of Anatomical Variations 2008;1:27-28.

3.Romanes G. Cunningham's Textbook of Anatomy (ed. 11) Oxford University Press. New York 1972:295.
4.Williams PL. Gray\&s anatomy: Churchill livingstone New York, 1995.

5.Srijit D, Shipra P. Spina bifida with higher position of sacral hiatus: a case report with clinical implications. Bratislavske lekarske listy 2007;108:467-469.

6.Schoenmakers M, Gulmans V, Gooskens R, Helders P. Spina bifida at the sacral level: more than minor gait disturbances. Clinical rehabilitation 2004;18:178-185.

7.Asher EF, Garrison RN, Ratcliffe DJ, Fry DE. Endotoxin, cellular function, and nutrient blood flow. Archives of surgery (Chicago, Ill : 1960) 1983;118:441445.

8.Findley TW, Agre JC, Habeck RV, Schmalz R, Birkebak RR, McNally MC. Ambulation in the adolescent with myelomeningocele. I: Early childhood predictors. Archives of physical medicine and rehabilitation 1987;68:518-522.

9.Hoffer MM, Feiwell E, Perry R, Perry J, Bonnett C. Functional ambulation in patients with myelomeningocele. The Journal of bone and joint surgery American volume 1973;55:137-148.

10.Albrecht TL, Scutter SD, Henneberg M. Radiographic method to assess the prevalence of sacral spina bifida occulta. Clinical anatomy (New York, NY) 2007;20:170174.

11.Barazi SA, Cudlip S, Johnston F. High and low pressure states associated with posterior sacral meningocele. British journal of neurosurgery 2003;17:184-187.

12.Wolf LS, McLaughlin JF. Early motor development in infants with meningomyelocele. Pediatric Physical Therapy 1992;4:12-17.

13.Ong LC, Lim YN, Sofiah A. Malaysian children with spina bifida: relationship between functional outcome and level of lesion. Singapore medical journal 2002;43:12-17.

14.Pierre-Kahn A, Zerah M, Renier D, et al. Congenital lumbosacral lipomas. Child's nervous system: ChNS: official journal of the International Society for Pediatric Neurosurgery 1997;13:298-334; discussion 335.

15.Holmbeck GN, Faier-Routman J. Spinal lesion level, shunt status, family relationships, and psychosocial adjustment in children and adolescents with spina bifida myelomeningocele. Journal of pediatric psychology 1995;20:817-832.

16.McDonald CM, Jaffe KM, Mosca VS, Shurtleff DB. Ambulatory outcome of children with 
DOI: 10.2478/romneu-2014-0029

myelomeningocele: effect of lower-extremity muscle strength. Developmental medicine and child neurology 1991;33:482-490.

17.Schwartz S, Cohen ME, Herbison GJ, Shah A. Relationship between two measures of upper extremity strength: manual muscle test compared to hand-held myometry. Archives of physical medicine and rehabilitation 1992;73:1063-1063.

18.Avrahami E, Frishman E, Fridman Z, Azor M. Spina bifida occulta of $\mathrm{S} 1$ is not an innocent finding. Spine 1994;19:12-15.

19.Fidas A, MacDonald HL, Elton RA, McInnes A, Wild SR, Chisholm GD. Prevalence of spina bifida occulta in patients with functional disorders of the lower urinary tract and its relation to urodynamic and neurophysiological measurements. BM) (Clinical research ed) 1989;298:357-359.

20.Galloway NT, Tainsh J. Minor defects of the sacrum and neurogenic bladder dysfunction. British journal of urology 1985;57:154-155.

21.de Anquin CE. SPINA BIFIDA OCCULTA WITH ENGAGEMENT OF THE FIFTH LUMBAR SPINOUS PROCESS A Cause of Low Back Pain and Sciatica. Journal of Bone \& Joint Surgery, British Volume 1959;41:486-490.

22.Sekiguchi M, Yabuki S, Satoh K, Kikuchi S. An anatomic study of the sacral hiatus: a basis for successful caudal epidural block. The Clinical journal of pain 2004;20:51-54. 